\title{
Tay-Sachs and French Canadians: A Case of Gene-Culture Co-Evolution?
}

\author{
Peter Frost \\ Bernard Saladin d'Anglure, Anthropology Department, Université Laval, Quebec City, Canada \\ Email: peter_frost61z@globetrotter.net
}

Received May $10^{\text {th }}$, 2012; revised June $15^{\text {th }}$, 2012; accepted June $27^{\text {th }}, 2012$

\begin{abstract}
Tay-Sachs, an inherited neurological disorder, is unusually common among French Canadians from eastern Quebec. Two alleles are responsible, one being specific to the north shore of the St. Lawrence and the other to the south shore. This pattern of convergent evolution suggests the presence of a selection pressure limited to eastern Quebec. Both alleles probably arose after the British conquest of Quebec in 1759 or at least were uncommon previously. To explain the high incidence of Tay-Sachs among Ashkenazi Jews, some authors have invoked heterozygote advantage, i.e., heterozygous individuals enjoy a higher rate of neuronal growth, and thus greater learning capacity, without the neurological deterioration of homozygous individuals. Such an advantage would have helped Ashkenazim perform the mental effort required for work in trade and crafts. A similar situation may have developed in eastern Quebec, where the relative scarcity of British and American merchants made it easier for French Canadians to enter occupations that required literacy, numeracy, and future time orientation.
\end{abstract}

Keywords: Neurological Disorder

\section{Introduction}

Tay-Sachs is an inherited neurological disorder caused by defective lysosomal storage in neural tissue. The earliest sign is usually an exaggerated startle response. Psychomotor deterioration appears around 4 to 6 months of age, followed by axial hypotonia, limb spasticity, seizures, and blindness. Progressive neurological deterioration leads to death by the age of four.

Tay-Sachs is common among Ashkenazi Jews of Eastern European origin and is often thought of as a Jewish disease. Yet it also reaches high incidences in a few other populations, particularly French Canadians.

Among French Canadians, it has three unusual characteristics:

1) It is highly localized geographically, being concentrated in eastern Quebec (Figure 1). In Rimouski, the heterozygote frequency is $7.6 \%$, versus $4.2 \%$ among Ashkenazi Jews and $0.3 \%$ among French Canadians in Montreal (De Braekeleer et al., 1992).

2) It is caused by two mutant alleles: one that arose on the north shore of the St. Lawrence (regions of Charlevoix, Saguenay, Lac Saint-Jean) and another that arose on the south shore (Bas Saint-Laurent) (Hechtman et al., 1992; Zlotogora, 1994; De Braekeleer, 1995).

3) It seems to be relatively recent in origin, these two alleles being absent in France. Both probably arose after the British conquest of Quebec in 1759 or at least were uncommon previously (Hechtman et al., 1992; De Braekeleer, 1995).

These characteristics are inconsistent with a founder effect, i.e., a chance deviation in gene frequency between a population and its parental stock. A founder effect might explain French Canadian Tay-Sachs if only one mutation were the cause. Here, two normally rare mutations, with the same physiological effect, have become prevalent within the same culture area in adjacent populations. This looks more like convergent evolution of two populations through a shared pressure of natural selection.

\section{Founder Effect?}

Yet the literature routinely explains French Canadian TaySachs as a founder effect. This is largely because eastern Quebec is home to other genetic disorders with similarly high incidences. There is thus a pattern of apparent founder effects that might reflect the area's ethnic homogeneity and historically fast population growth.

These other eastern Quebec disorders nonetheless resemble Tay-Sachs in one respect. Of the top ten, six are primarily neurological and two secondarily so (Table 1; Laberge et al., 2005). Is this pattern typical? Of the top ten genetic disorders in the United Kingdom, only three are primarily or secondarily neurological (Table 2) (Genetic Alliance UK, 2010).

One of the eastern Quebec disorders, mucolipidosis type II, is a lysosomal storage disease like Tay-Sachs. It reaches a heterozygote frequency of $2.6 \%$ in the regions of Saguenay and Lac Saint-Jean, the highest reported rate for this disorder (Plante et al., 2008). French Canadians are also thought to have high incidences of two other lysosomal storage diseases: Gaucher's disease and mucopolysaccharidosis type IV (Laberge et al., 2005).

\section{Natural Selection?}

The alternate explanation, natural selection, implies that carriers of Tay-Sachs enjoy an advantage over non-carriers, specifically a reproductive one. Such an advantage may seem unlikely, since Tay-Sachs leads to early death and no reproduction. But this outcome happens only if the carrier has both copies of a Tay-Sachs allele (homozygote) and not just one (heterozygote). 


\section{P. FROST}

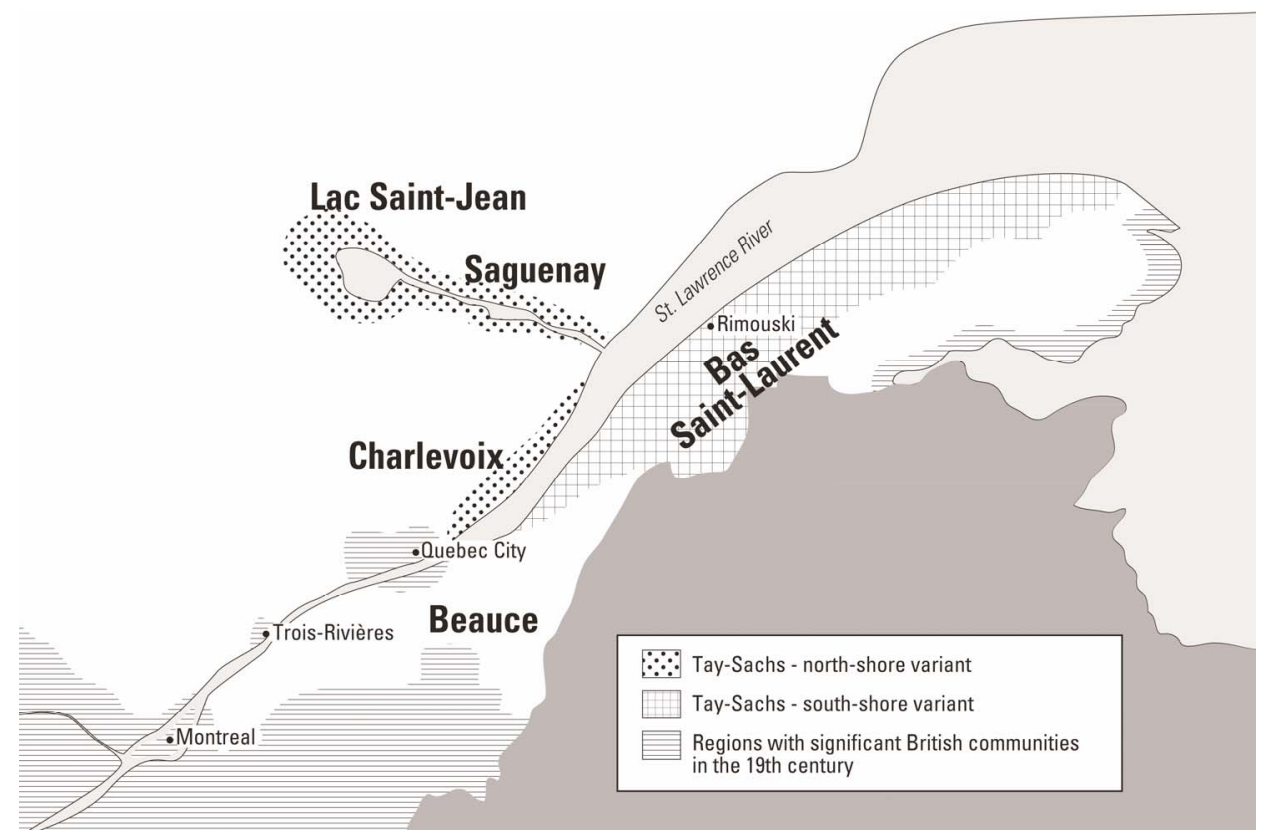

Figure 1.

Areas of high Tay-Sachs prevalence in Eastern Quebec.

Table 1.

Genetic disorders with higher incidences in Eastern Quebec.

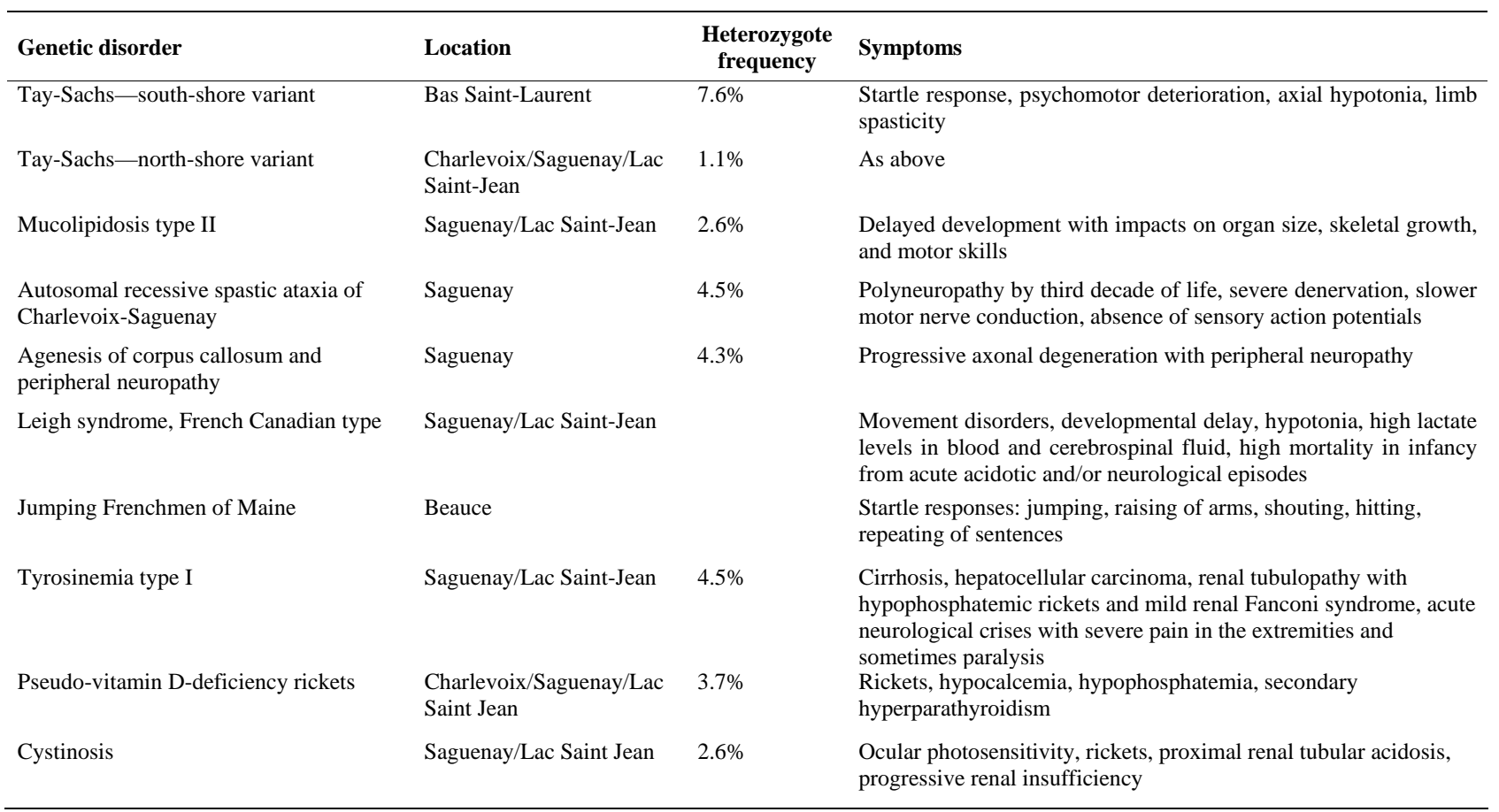

Sources: Laberge et al. (2005); Braekeleer (1995).

Because the second situation is much more common than the first, the slight advantage of having one copy could offset the great disadvantage of having two.

This argument has been used to explain why Ashkenazi Jews have high incidences of four lysosomal storage disorders: Tay-Sachs, Gaucher's, Niemann-Pick, and mucolipidosis type IV (Cochran et al., 2006). These disorders lead to excessive storage by lysosomes of sphingolipids, a substance that promotes growth of neural axons and that may thus increase learning capacity. It is perhaps for this reason that engineers and scientists are at least six times more common among Israelis with Gaucher's disease than among Ashkenazi Jews in general. Heterozygous individuals should have modestly higher sphingolipid storage and a correspondingly higher IQ, "probably in 
Table 2.

Top ten genetic disorders in the United Kingdom.

\begin{tabular}{|c|c|c|}
\hline Genetic disorder & Incidence (per 1000 births) & Symptoms \\
\hline Familial combined hyperlipidemia & 5.0 & High cholesterol levels, leading to heart disease \\
\hline Familial hypercholesterolemia & 2.0 & High cholesterol levels, leading to heart disease \\
\hline Dominant otosclerosis & 1.0 & Abnormal bone growth near the middle ear \\
\hline Adult polycystic kidney disease & 0.8 & Cysts that destroy the kidney \\
\hline Multiple exostoses & 0.5 & Bony spurs or lumps that develop on the skeleton \\
\hline Huntington's disease & 0.5 & $\begin{array}{l}\text { Neurodegeneration, leading to loss of muscle coordination, cognitive } \\
\text { decline, and dementia }\end{array}$ \\
\hline Fragile $\mathrm{X}$ syndrome & 0.5 & Autism and intellectual disability \\
\hline Neurofibromatosis & 0.4 & Tumors that develop out of nerve tissue \\
\hline Cystic fibrosis & 0.4 & Defective production of sweat, digestive juices, and mucus \\
\hline Duchenne muscular dystrophy & 0.3 & Muscle degeneration \\
\hline
\end{tabular}

Source: Genetic Alliance UK (2010).

the order of 5 points” (Cochran et al., 2006: p. 677).

This neural advantage should have helped many Ashkenazi Jews adapt to tasks that require literacy, numeracy, and future time orientation, notably the buying and selling of goods and the making of crafts for urban markets (Cochran et al., 2006; Murray, 2007). The Tay-Sachs allele would have thus become more common, since the more successful traders and artisans contributed disproportionately to population growth, particularly the surge from about 100,000 Ashkenazim in 1650 to 5 million in 1900 (Risch et al., 1995).

\section{Tay-Sachs in French Canada: Historical and Economic Background}

Is Tay-Sachs common in eastern Quebec for the same reason? The idea might seem farfetched. Were not French Canadians historically a nation of farmers? And were not English Canadians the businessmen?

In reality, there had always been some French Canadian businessmen, but their numbers were constrained by cultural and even legal barriers or by competition from British and American immigrants. These constraints varied in strength over time and space. Whereas cultural and legal barriers were stronger under the French Regime, immigrant competition was stronger under the British Regime, especially in western and central Quebec.

\section{French Regime (1608-1759)}

The French colonists saw the market as a very secondary source of the necessities of life. In the countryside, where threequarters of them lived, almost all food, clothing, and furnishings were produced within the family. Although people also worked outside the family, such labor was usually not bought or sold but instead supplied under long-term agreements of mutual assistance, such as between tenant farmers and their seigneur. Farming itself was primarily for subsistence and only secondarily for sale of surplus produce to middlemen. Wheat yields were only 4 to 6 bushels per arpent (0.85 acre) (Ouellet, 1966: pp. 8-9, 52-53, 81-82).

In the towns, markets did exist but were State-regulated.
Government officials controlled food prices and wholesale trade (Vallières et al., 2008: pp. 219, 223, 520, 521). To give consumers first priority, merchants were forbidden to purchase from farmers directly and before certain hours of the morning (Vallières et al., 2008: p. 505). Urban markets were localized in space and time, being typically marketplaces where buyer and seller met face to face and personally supervised each transaction. These oases of trade could not coalesce into a true market economy largely because buyers and sellers trusted each other so little.

If lack of trust confined the market economy to isolated points in space, lack of foresight confined it to the present point of time. People tended to sacrifice future needs for short-term gains, as noted by the Jesuit missionary and explorer PierreFrançois-Xavier de Charlevoix:

The English colonist amasses worldly goods and makes no superfluous expenses; the French colonist enjoys what he has, and often shows off what he has not. The former works for his heirs; the latter leaves his own in need... (Ouellet, 1966: p. 7).

This was one reason why the French government distrusted the market mechanism and felt obliged to act on behalf of long-term interests. After the conquest, the first British governor felt similarly, seeing therein an obstacle to development of a true market economy:

... the inhabitants are inclinable enough to be lazy, and not much skilled in Husbandry. The great dependancies they have hitherto had on the Gun and fishing rod, (which) made them neglect tillage beyond the requisites of their own consumption and the few purchases they needed, the Monopolies that were carried on here in every branch, (which) made them careless of acquiring beyond the present use, and their being often sent on distant parties and detachments, to serve the particular purposes of greedy and avaricious men without the least view to public utility, were circumstances under which no country could thrive (Murray, 1902 (1762): pp. 51-52).

\section{British Regime and after (1759-)}

The British conquest of 1759 put Quebec on the road to a more market-driven economy. Great Britain itself was moving in the same direction with its growing advocacy of free trade and rejection of mercantilism. On a more local level, the con- 
quest weakened groups that previously had State backing, thereby freeing up room for merchants, petty traders, self-employed artisans, and other entrepreneurs who could navigate in the new economic environment.

A gulf developed between the landed gentry, who thought of society in terms of absolutism, feudalism, bureaucracy, birth, and tradition, and the middle class (bourgeoisie) who now intended to redefine society in terms of its values. This was perhaps one of the most important consequences of the conquest. The bureaucracy as well as the landed gentry and the military elite saw their social role challenged by a middle class that demanded its autonomy and that intended to exercise a social influence in proportion to its economic dynamism (Ouellet, 1966: p. 96).

This ascendant class was filled by British and American immigrants in western and central Quebec, particularly in the Ottawa Valley, Montreal, Trois-Rivières, Quebec City, and the Eastern Townships. A similar situation prevailed on the southern and eastern shores of the Gaspé Peninsula (Figure 1).

In contrast, such immigrants were scarce over much of eastern Quebec, i.e., the Charlevoix, Saguenay, and Lac Saint-Jean regions on the north shore of the St. Lawrence and the Beauce and Bas Saint-Laurent regions on the south shore. Since this territory lay farther from the American border and lacked major ports, it became home overwhelmingly to local settlers of French descent. Nonetheless, its built environment-roads, bridges, buildings, etc.-was almost wholly British in design because settlement was largely post-conquest. Social structures were likewise less influenced by the French Regime. The seigneurial system lasted only a few decades in Bas Saint-Laurent versus nearly two centuries farther upriver (Fortin \& Lechasseur, 1993: p. 311).

The absence of English-speaking immigrants was striking to Alexis de Tocqueville when he passed through Bas SaintLaurent in 1831:

In this portion of Canada, one does not hear English at all. The population is only French, and yet when one encounters an inn, or a merchant, the sign is in English (De Tocqueville, 2003 (1831), p. 185).

With little competition from British or American merchants, an enviable niche opened up for French Canadians, or rather for those with the right abilities. In the Saguenay region during the 19th century:

Success in trade was never easy because of the competition, the fragility of the markets, and the instability of business conditions. The ablest managed to live or survive. Others, the greatest number, closed shop after a few years. Only those possessing exceptional qualities would make a fortune (Lapointe, 1996: p. 3).

Likewise in the Beauce region, "out of ten merchants who remained more than ten years in business, only four or five succeeded" (Courville et al., 2003: p. 257).

Success required special talents. This point is made in a biography of John Guay (1828-1880), a leading French Canadian merchant of the Saguenay region:

Improvising one's way into becoming a merchant is not possible for anyone who so wishes. It takes talent and of course capital. Spontaneous generation was very uncommon in 19thcentury Quebec, indeed nonexistent in John Guay's case. The family environment in which he grew up predisposed him to develop an interest and also aptitudes for the businesses of trade, forestry, and farming. His successful career henceforth proved that a French Canadian merchant could ably penetrate the world of business; a world where, let us remember, English Canadians controlled most of the commercial and industrial activities (Lapointe, 1996: p. 126).

How did French Canadians penetrate the world of business? John Guay's father built bridges, wharfs, and sawmills on contract before becoming a merchant (Lapointe, 1996: pp. 18-24). In the Beauce region, such people began as innkeepers, as tavern operators, or as farmers who worked on the side as livestock or grain dealers (Bélanger et al., 1990: p. 62; Courville et al., 2003: pp. 261-262). Often, the initial line of work would never be fully given up, a reason perhaps why so many French Canadian merchants of the 19th century failed to identify themselves as such to census takers (Courville et al., 2003: pp. 261-262). It may also be that the title of marchand or commerçant was viewed as somewhat disreputable.

To become a full-fledged merchant, the preconditions seem to have been familiarity with cash transactions and frequent negotiation of agreements on a case-by-case basis. A third one was a certain outlook on life. This precondition has been discussed by the historical economist Gregory Clark with respect to England from the 12th century onward. As England became a settled society, with the State imposing a monopoly on violence, successful individuals were those who could settle disputes amiably and profit from current actions further into the future - in short, those who had middle-class values of thrift, foresight, self-control, and sobriety (Clark, 2007).

\section{Expansion of a Market-Oriented Middle Class}

Such individuals were initially a small minority in England. Their descendants, however, steadily grew in number and replaced the lower classes through downward mobility, eventually accounting for most of the population by the 1800s. Their values came to dominate English society and laid the moral, cultural, and behavioral basis for the Industrial Revolution (Clark, 2007, 2009a, 2009b).

The Industrial Revolution would end this process of demographic change. Previously, production took place in family-run cottage industries whose owners, if successful, expanded their workforces by having bigger families (Seccombe, 1992: pp. 182-183, 205-206). Now, production was in factories whose owners simply hired as many workers as they wished. These new industrialists did not translate their economic success into reproductive success. Henry Ford, for instance, had only one child.

In Quebec, the family remained the most common unit of production well into the 20th century. This was especially so on farms and in small businesses that dealt directly with the market economy while keeping the actual production process in a pre-market economy of unpaid family labor. There was thus a strong incentive to have children. In Quebec City, at the turn of the 20th century, the fertility rate was higher among French Canadians who worked for themselves at home than among those who worked for an employer at another location. A home-based shoemaker could bring his wife and children into different stages of production, i.e., cutting the hides, dyeing, sewing, fitting pieces together, etc. This family assistance was unavailable to wage-earning factory employees (Marcoux et al., 2006: pp. 73-85; Marcoux, 2009: pp. 107-120).

Like crafts men and women, merchants had access to child labor. In addition, they could earn much more than the average 
French Canadian and thus benefit from a positive feedback between family size and income. The merchant John Guay had ten children who lived to adulthood, twice the average of French Canadians of his time (Lapointe, 1996: p. 110).

In all this, what mattered was not so much one's occupation per se as one's access to the market economy, a factor that varied within each occupation. Farming, for instance, ranged from subsistence agriculture to market gardening. Whatever the line of work, by better exploiting the possibilities of the market economy, one could generally earn more income and support more children, who in turn could marry earlier and have larger families of their own. More income also meant less mortality, especially infant mortality-a major curb on reproductive success until the 20th century.

This factor might explain why fertility correlated positively with literacy in all occupations of the Saguenay region throughout the 19th century and long after. Literate individuals may have had more resources for family formation, being better able to navigate in the market economy and needing less supervision by third parties (employer, manager, custodian, etc.). This correlation would not become negative until 1946-1955 among farmers and 1931-1935 in other occupations, a reversal that came much later than elsewhere apparently because of the Roman Catholic Church's hostility to contraception (Bouchard \& Roy, 1991).

\section{Baldwinian Selection}

The growing number of market-oriented individuals - in short, the middle class - created a distinct cultural environment with its own norms. To succeed in this environment, one had to adapt, just as humans have had to adapt to different climates, landscapes, and food sources.

Cultural evolution thus paved the way for biological evolution. This process, called Baldwinian selection, can be broken down into three stages:

1) Individuals adhere to a desired behavior through conscious effort, within an envelope of possibilities allowed by their genetic endowment.

2) These actions create a new cultural environment, which in turn selects for genotypes that more easily produce the desired behavior. A heritable predisposition increasingly takes over from conscious effort.

3) The result is a shift toward a new mean genotype and a new envelope of possible phenotypes.

This kind of gene-culture co-evolution may explain the high incidence of Tay-Sachs and other disorders in eastern Quebec. Such disorders would be only the tip of the iceberg, i.e., the most harmful outcomes among a much larger number of generally benign outcomes. We know less about the latter because there is less interest in genetic traits that cause no harm.

\section{Discussion}

Have French Canadians been shaped by gene-culture coevolution? The possibility is intriguing but raises several questions.

\section{Was There Enough Time?}

One is the length of time. How could natural selection have produced significant genetic change over a span of two and a half centuries? This is a mere ten generations. Yet the time span could not have been much greater. Given that the two TaySachs mutations are absent in France and uncommon over most of Quebec, both alleles must have reached their currently high prevalence in eastern Quebec after French Canadians had begun to settle that area.

If the Tay-Sachs heterozygote frequency had been $0.3 \%$ among French Canadians at the time of the conquest, ten generations could have been enough to bring it up to the current level of $7.6 \%$ in Rimouski if we assume a $25 \%$ - 30\% fitness advantage. In addition, there may have been selection effects from the mass out-migration of the late 19th century when many French Canadians left the area for factory work in New England. The emigrants tended to be landless farmers, rather than merchants, and may have been less likely to carry the TaySachs allele.

Such rapid evolution seems to have been common in our species. Natural selection has altered at least $7 \%$ of the human genome over the last 40 thousand years, with most of the change happening since agriculture emerged less than ten thousand years ago. At that time, the rate of genetic change may have increased over a hundred-fold (Hawks et al., 2007). This rapid evolution seems to reflect rapid adaptation to a wide range of new environments: not only physical environments defined by climate, landscape, and vegetation, but also cultural environments defined by technology, social structure, and codified rules of behavior.

This kind of gene-culture co-evolution has recently been shown among French Canadians, specifically those inhabiting the island of Île aux Coudres in the St. Lawrence. Its settlers came from a land-poor environment where young people postponed marriage until their parents handed over the farm. Emigration to New France, where farmland was much more plentiful, dramatically lowered the age of marriage. This decline in the age of marriage was followed by a decline in the mean age of first reproduction (AFR). From 1800 to 1940, AFR fell by four years. This second decline was due not to a lowering of the mean age of marriage (now stable) but to a shortening of the mean interval between marriage and first birth. The ultimate cause could not have been a change in nutrition. Nor could it have been some kind of cultural lag, since AFR fell at the same rate throughout this period. The likeliest explanation is a gradual shift in the gene pool due to a growing number of highly fertile couples who could better exploit the opportunities for early family formation (Milot et al., 2011).

\section{The Beauce Region}

The Beauce region stretches southeast of Quebec City and covers the Chaudière valley up to the American border. Like the rest of eastern Quebec, it has had relatively little settlement by English-speakers and has thus developed its own middle class, so much so that Beaucerons are stereotyped as businessminded go-getters - the "Yankees" of Quebec. Yet this same region has low incidences of Tay-Sachs and also of most of the other disorders that are frequent in eastern Quebec.

Something else, however, distinguishes the Beauce region from the rest of eastern Quebec. Settlers arrived there earlier than elsewhere. They also seem to have been less homogeneous, coming from a wider range of regions in France and including discharged German mercenaries (Ferron \& Cliché, 1982: pp. 3$4,123-124)$. This larger and more diverse gene pool may have supplied a greater number of suitable individuals for the niches 
that opened up after the conquest, as Quebec moved from a semi-feudal society to a market-driven one. Natural selection had more leeway to favor new genetic variants that cause fewer harmful side effects.

\section{Tay-Sachs Elsewhere in North America}

High incidences of Tay-Sachs have been reported from three other groups in North America: the Cajuns of Louisiana; a Pennsylvania Dutch community; and people of Irish origin (Branda et al., 2004; Kelly et al., 1975; McDowell et al., 1992; Mules et al., 1992). In the second group, the cause may be a founder effect, since there is no exclusive geographic or social basis. The disease occurs within several related families who form 3\% of the population of two townships (Kelly et al., 1975). On the other hand, two separate alleles are responsible, despite the small size of this semi-isolate (Mules et al., 1992). A founder effect less easily explains Tay-Sachs among the Cajuns and the Irish, who have multiple Tay-Sachs alleles and form geographically or ethnically circumscribed groups (Branda et al., 2004; McDowell et al., 1992).

The Cajuns and the Irish may have likewise gone through this kind of gene-culture co-evolution. Like the French Canadians of eastern Quebec, they made the transition to a market economy later and more quickly than the English did. It may be that their market-savvy individuals tended to have a less optimal mix of genetic factors, including alleles like Tay-Sachs that are detrimental in homozygotes though useful in heterozygotes.

\section{Why Are Vitamin-D Deficiency Disorders Also More Prevalent?}

Finally, although gene-culture co-evolution might explain why certain neurological disorders occur more often in eastern Quebec than elsewhere, it less easily explains the higher prevalence of two apparently non-neurological disorders: pseudovitamin-D deficiency rickets and cystinosis. Both lead to rickets through an inability to synthesize or process enough vitamin D. This symptom is also associated with a third eastern Quebec disorder: Tyrosinemia type I. In comparison, rickets is not caused by any of the top ten genetic disorders in the United Kingdom.

Vitamin-D deficiency does not seem to affect adult cognition, at least not according to a recent review article (Annweiler et al., 2009). But there may be early developmental effects. When rat fetuses are deprived of vitamin-D, the newborn pups have larger brain volumes and show more cell proliferation throughout their brains. This is consistent with the antiproliferative effect of this vitamin on body tissues. Prenatal vitamin-D deficiency seems to increase the rate of neuronal proliferation while decreasing the rate of neuronal cell death (Eyles et al., 2003). If prenatal vitamin-D deficiency affects humans similarly, the result may be improved cognitive performance, albeit at a high cost for homozygous individuals. As with Tay-Sachs, the more numerous heterozygous individuals should enjoy a lower cost/ benefit ratio.

\section{REFERENCES}

Annweiler, C., Allali, G., Allain, P., Bridenbaugh, S., Schott, A.-M., Kressig, R. W., \& Beauchet, O. (2009). Vitamin D and cognitive performance in adults: A systematic review. European Journal of Neurology, 16, 1083-1089. doi:10.1111/j.1468-1331.2009.02755.x
Bélanger, F., Berberi, S., Breton, J.-R., Carrier, D., \& Lessard, R. (1990). La Beauce et les Beaucerons. Portraits d'une région 1737-1987. Saint-Joseph-de-Beauce: La Société du patrimoine des Beaucerons.

Bouchard, G., \& Roy, R. (1991). Fécondité et alphabétisation au Saguenay et au Québec (XIXe-XXe siècles). Annales de démographie historique, 3, 173-201.

Branda, K. J., Tomczak, J., \& Natowicz, M. R. (2004). Heterozygosity for Tay-Sachs and Sandhoff diseases in Non-Jewish Americans with ancestry from Ireland, Great Britain, or Italy. Genetic Testing, 8, 174-180. doi:10.1089/gte.2004.8.174

Clark, G. (2009a). The indicted and the wealthy: Surnames, reproductive success, genetic selection and social class in pre-industrial England.

http://www.econ.ucdavis.edu/faculty/gclark/Farewell\%20to\%20Alm s/Clark\%20-Surnames.pdf

Clark, G. (2009b). The domestication of man: The social implications of Darwin. ArtefaCTos, 2, 64-80.

Clark, G. (2007). A farewell to alms. A brief economic history of the world. Princeton: Princeton University Press.

Cochran, G., Hardy, J., \& Harpending, H. (2006). Natural history of Ashkenazi intelligence. Journal of Biosocial Science, 38, 659-693. doi:10.1017/S0021932005027069

Courville, S., Poulin, P. C., Rodrigue, B., Allard, M., Girard, D., Grenier, F., Hatvany, M., Larocque, M.-J., Mcquillan, A., Poulin, P., Pronovost, C., Routhier, G., Schwartz, K., \& St-Hilaire, M. (2003). Histoire de Beauce-Etchemin-Amiante. Quebec City: Presses de l’Université Laval.

De Braekeleer, M. (1995). Inbreeding, kinship and surnames in hereditary disorders: The experience in Saguenay-Lac-Saint-Jean (Quebec). Collegium Antropologicum, 19, 289-304.

De Braekeleer, M., Hechtman, P., Andermann, E., \& Kaplan, F. (1992). The French Canadian Tay-Sachs disease deletion mutation: Identification of probable founders. Human Genetics, 89, 83-87. doi:10.1007/BF00207048

De Tocqueville, A. (2003) [1831]. Regards sur le Bas-Canada. Montreal: Typo.

Eyles, D., Brown, J., Mackay-Sim, A., Mcgrath, J., \& Feron, F. (2003). Vitamin $\mathrm{D}_{3}$ and brain development. Neuroscience, 118, 641-653. doi:10.1016/S0306-4522(03)00040-X

Ferron, M., \& Cliché, R. (1982). Les Beaucerons. Ces insoumis, suivi de Quand le peuple fait la loi. Montreal: Hurtubise HMH.

Fortin, J.-C., \& Lechasseur, A. (1993). Histoire du Bas-Saint-Laurent. Quebec City: Presses de l’Université Laval.

Genetic Alliance UK (2010). Incidence of genetic disorders, URL (last checked 25 June 2012).

http://www.geneticalliance.org.uk/education3.htm

Hawks, J., Wang, E. T., Cochran, G. M., Harpending, H. C., \& Moyzis, R. K. (2007). Recent acceleration of human adaptive evolution. Proceedings of the National Academy of Sciences of USA, 104, 2075320758.

Hechtman, P., Boulay, B., De Braekeleer, M., Andermann, E., Melançon, S., Larochelle, J., Prevost, C., \& Kaplan, F. (1992). The intron 7 donor splice site transition: A second Tay-Sachs disease mutation in French Canada. Human Genetics, 90, 402-406. doi:10.1007/BF00220467

Kelly, T. E., Chase, G. A., Kaback, M. M., Kumor, K., \& McKusick, V. A. (1975). Tay-Sachs disease: High gene frequency in a non-Jewish population. American Journal of Human Genetics, 27, 287-291.

Laberge, A.-M., Michaud, J., Richter, A., Lemyre, E., Lambert, M., Brais, B., \& Mitchell, G. A. (2005). Population history and its impact on medical genetics in Quebec. Clinical Genetics, 68, 287-301. doi:10.1111/j.1399-0004.2005.00497.x

Lapointe, N. (1996). Le capitalisme marchand au Saguenay-Lac-SaintJean: John Guay (1828-1880), négociant et propriétaire foncier. Master's Thesis, Quebec City: Université du Québec à Chicoutimi.

Marcoux, R. (2009). Transition démographique et mise au travail des enfants dans la ville de Québec à la fin du XIX ${ }^{\mathrm{e}}$ siècle. In B. Caulier, \& Y. Rousseau (Eds.), Temps, espace et modernités (pp. 107-120). Quebec City: Presses de l’Université Laval.

Marcoux, R., St. Hilaire, M., \& Harton, M.-E. (2006). Modes de pro- 


\section{P. FROST}

duction et comportements en matière de fécondité à Québec au début du $20^{\mathrm{e}}$ siècle: La nécessité de saisir le travail des femmes en milieu urbain. Population et travail-Dynamique démographique et travail (pp. 73-85). Actes des Colloques de l'AIDELF.

McDowell, G. A., Mules, E. H., Fabacher, P., Shapira, E., \& Blitzer, M. G. (1992). The presence of two different infantile Tay-Sachs disease mutations in a Cajun population. American Journal of Human Genetics, 51, 1071-1077.

Milot, E., Mayer, F. M., Nussey, D. H., Boisvert, M., Pelletier, F., \& Réale, D. (2011). Evidence for evolution in response to natural selection in a contemporary human population, Proceedings of the $\mathrm{Na}$ tional Academy of Sciences of USA, 108, 17040-17045. doi:10.1073/pnas.1104210108

Mules, E. H., Hayflick, S., Dowling, C. E., Kelly, T. E., Akerman, B. R., Gravel, R. A., \& Thomas, G. H. (1992). Molecular basis of Hexosamininidase A deficiency and pseudodeficiency in the Berks County Pennsylvania Dutch. Human Mutation, 1, 298-302. doi:10.1002/humu.1380010406

Murray, C. (2007). Jewish genius. Commentary, April.

Murray, J. (1902). [1762]. Report of the state of the government of Quebec in Canada. Quebec City: Dussault \& Proulx.

Ouellet, F. (1966). Histoire économique et sociale du Québec 1760-
1850, structures et conjoncture. Fides: Montreal and Paris.

Plante, M., Claveau, S., Lepage, P., Lavoie, E.-M., Brunet, S., Roquis, D., Morin, C., Vézina, H., \& Laprise, C. (2008). Mucolipidosis II: A single causal mutation in the $\mathrm{N}$-acetylglucosamine-1-phosphotransferase gene (GNPTAB) in a French Canadian founder population. Clinical Genetics, 73, 236-244. doi:10.1111/j.1399-0004.2007.00954.x

Risch, N., De Leon, D., Ozelius, L., Kramer, P., Almasy, L., Singer, B., Fahn, S., Breakefield, X., \& Bressman, S. (1995). Genetic analysis of idiopathic torsion dystonia in Ashkenazi Jews and their recent descent from a small founder population. Nature Genetics, 9, 152-159. doi:10.1038/ng0295-152

Seccombe, W. (1992). A millennium of family change. Feudalism to capitalism in Northwestern Europe. London: Verso.

Vallières, M., Desloges, Y., Harvey, F., Heroux, A., Auger, R., Lamontagne, S.-L., \& Charbonneau, A. (2008). Histoire de Québec et de sa région. Tome I. Des origines à 1791. Quebec City: Presses de l’Université Laval.

Zlotogora, J. (1994). High frequencies of human genetic diseases: Founder effect with genetic drift or selection? American Journal of Medical Genetics, 49, 10-13. doi:10.1002/ajmg.1320490104 